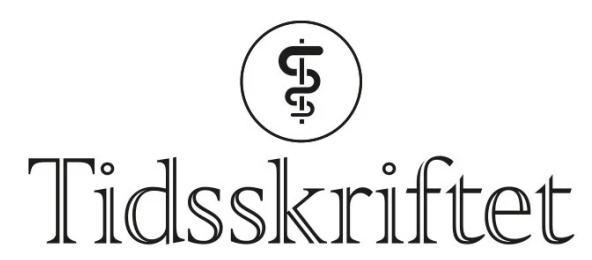

DEN NORSKE LEGEFORENING

\title{
Nyoppdaget mekanisme for luktpersepsjon
}

FRA ANDRE TIDSSKRIFTER

HAAKON B. BENESTAD

Universitetet i Oslo

$\AA ̊$ kjenne duften av kaffe - med hundrevis av ulike luktmolekyler - kan bero på luktmolekylenes gjensidige virkning på sansecellene.

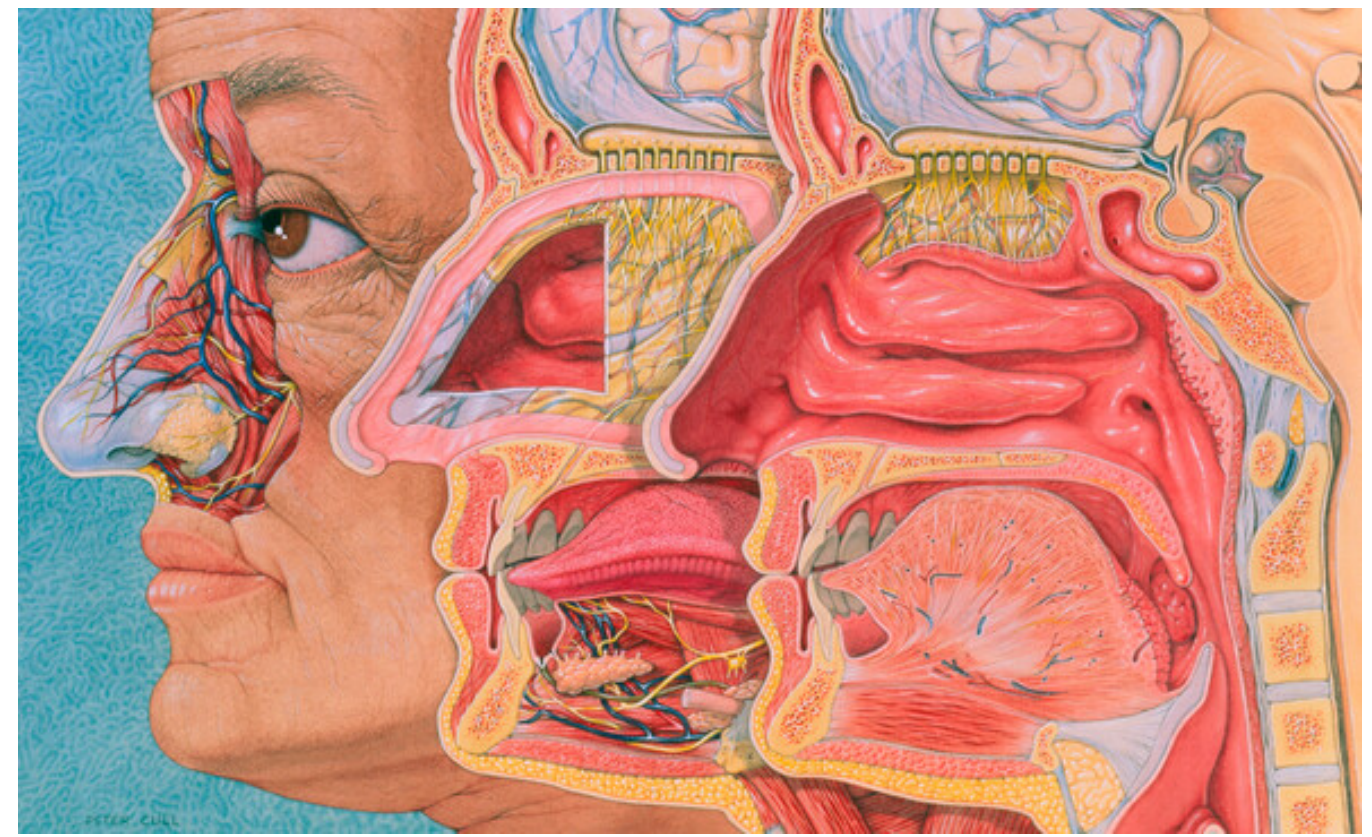

Illustrasjonsfoto: Science Photo Library / NTB Scanpix

Vanlig oppfatning er at flyktige, organiske molekyler som vi kan lukte, stimulerer et utvalg av nesten tusen ulike sansenevroner i taket av nesehulen. Hvert sansenevron har reseptorer for bare én type luktmolekyl. Man har derfor antatt at ulike lukter oppstår ved stimulering av ulike utvalg av nevroner. Dette har vært grundig undersøkt ved å stimulere med én type luktmolekyl av gangen, men problemet er å forstå hvordan vi oppfatter en blanding av luktmolekyler. 
Denne problemstillingen er nå forsket på hos mus med bruk av en ny mikroskopimetode (1). Metoden registrerer aktiviteten parallelt i tusenvis av luktnevroner når luktstoffer tilføres nesehulen. Gjennom mikroskopet filmes graden av aktivering av hver enkelt sansecelle.

Studien ga ikke de resultatene man kunne forvente. Det var ikke slik at virkningen på én sansecelle som stimuleres av flere luktstoffer samtidig, var en enkel summasjon av hvert enkelt luktstoffs effekt. Derimot fantes både agonistisk og antagonistisk responsmodulering - til og med at et molekyl som ikke aktiverte en spesiell reseptorcelle, kunne påvirke effekten av et annet molekyl på den samme cellen.

- At et luktstoff kan hemme persepsjonen av et annet luktstoff, har man kjent til tidligere, men at dette kan forekomme allerede i sansecellene, er svært overraskende, sier Torkel Hafting, som er førsteamanuensis ved Institutt for medisinske basalfag, Universitetet i Oslo. Uten den nyoppdagete modulatoriske aktiviteten i sansecellene har det vært et problem å forklare hvordan pattedyr kan skille mellom så utrolig mange komplekse dufter - ikke minst at vi kan gjenkjenne enkelte duftstoffer for eksempel i en god vin.

Hva er så mekanismen bak? Har disse luktreseptorene allosteriske bindingsseter, slik at en luktcelle som normalt responderer på lukt $\mathrm{A}$ og ikke $\mathrm{B}$, vil få en annen respons på A+Bmiksen fordi $B$ binder seg et annet sted på reseptoren enn $A$ og dermed påvirker responsen til A? I andre sansesystemer skjer denne agonist-antagonist-moduleringen ikke direkte på sansecellene, men senere, mellom nervecellene som bringer informasjonen mot hjernebarken, sier Hafting.

\section{LITTERATUR}

1. Xu L, Li W, Voleti V et al. Widespread receptor-driven modulation in peripheral olfactory coding. Science 2020;368: eaaz539o. [PubMed][CrossRef]

Publisert: 13. august 2020. Tidsskr Nor Legeforen. DOI: 10.4045/tidsskr.20.0517

(C) Tidsskrift for Den norske legeforening 2023. Lastet ned fra tidsskriftet.no 26. april 2023. 